\title{
AN APORIA BRED FROM LIMACODES SP.
}

\author{
BY C. H. TYLER TOWNSEND, LAS CRUCES, N. MEX.
}

The Tachinid described below occurs in a lot of Tachinidae sent me by Professor Comstock, from Ithaca, N. Y. Aside from the knowledge of its parasitism, it is of peculiar interest as belonging to the genus Aporia, hitherto recorded only from South America. This genus differs from Exorista, to which it is nearly allied, by the frontal bristles not descending below base of antennae, and the antennae being inserted below a line drawn through the middle of the eyes. The third antennal joint is also considerably narrowed, and the whole body is very bristly.

Aporia limacodis n. sp. §. Eyes cinnamon brown, thickly pubescent; front very narrow, about as wide as one of the antennal joints on posterior half, gradually widening before; frontal vitta nearly obsolete behind, wide and triangular in front, velvet brown; frontal bristles moderately strong and all directed forward, absent just before ocelli, ocellar and vertical bristles hardly to be distinguished, all directed forward, no orbital bristles; sides of front, face and cheeks silvery white, the cheeks hardly one-third eye-hight and with a few bristles on lower portion, sides of face narrow and bare; vibrissae decussate and inserted on oral margin, facial ridges bare except several bristles next vibrissae; antennae and arista black, first two antennal joints and base of third rufous; proboscis short, fleshy, brownish, labella large and tawny; palpi not large, rufous, bristly, a little enlarged apically; occiput silvery, clothed with gray hairs. Thorax wider than head or abdomen, shin- ing black, rather thinly silvery white pollinose, with four black vittae, the outer ones interrupted at suture, humeri and pleurae more distinctly silvery white pollinose; scutellum black, silvery, with an apical decussate pair of macrochaetae and two lateral ones, the posterior lateral ones strongest. Abdomen narrower than thorax, long conical, very bristly and hairy, shining black, basal half or more of segments two to four silvery white pollinose, first segment silvery beneath and faintly so on sides above: first segment with a strong lateral macrochaeta and a median marginal pair; second with a median discal pair and a marginal row of six or eight; third with a median discal pair and a marginal row of ten; anal beset with macrochaetae except at base, second and third segments with median anterior and submarginal pairs of macrochaeta-like bristles. Legs rather long, blackish, front femora silvery white pollinose on outside, tibiae pale brownish rufous, bristly, claws and pulvilli elongate, pulvilli smoky yellowish. Wings longer than abdomen, rather hyaline, somewhat grayish, no stump or wrinkle at bend of fourth vein, tegulae nearly white, halteres tawny.

Length of body, $9.5 \mathrm{~mm}$; of wing, $8 \mathrm{~mm}$.

Described from one specimen; Ithaca, N. Y. Bred by Professor J. H. Comstock from Limacodes sp. Issued May 30.

A female which may belong to this species was also sent me by Professor Comstock; it was collected June 28 by Mr. S. H. Crossman, and differs as follows :

More generally silvery white pollinose; 
front one-fourth width of head, of equal width, frontal bristles stronger, two orbital bristles directed strongly forward; third antennal joint not so narrowed, palpi and labella more yellow. Macrochaetae of abdomen more differentiated from the macrochaeta- like bristles, which latter are very much weaker; claws and pulvilli only a little elongate. Abdomen less conical and nearly as wide as thorax.

Length of body, nearly $7 \mathrm{~mm}$.; of wing, $6 \mathrm{~mm}$.

\section{THE EARLY STAGES OF NERICE BIDENTATA.}

\section{BY CAROLINE G. SOULE, BROOKLINE, MASS.}

The egg, found on the under side of an elm leaf, Aug. 9, I891, was hemispherical, the flat side being attached to the leaf. It was greenish yellow with a whitish bloom over it, and was very like the egg of Nadata gibbosa. It hatched on Aug. 13th.

The young larva was $\frac{3}{16}$ inch long, of a deep green color, and with sparse hairs. Head brown, lighter on the median suture. The fifth segment had a dorsal and substigmatal spot of shining brown, and the IIth segment had a dorsal spot of the same color. The feet and props were shining brown in color. Anal props were very slender and were raised when the larva walked. The body, at rest, was arched between the feet and abdominal props, and between the abdominal and anal props.

Aug. I6. Ist moult. Length $\frac{1}{4}$ inch. Head large, almost round, bilobed, pale olive green with dark green face-lines. Body pale glassy green, darker on the dorsum. The glassy effect was striking. 5th segment had a large brown double tubercle on the dorsum, and a substigmatal, smaller one on each side. The tenth segment had a substigmatal brown patch on each side, and the IIth a brown single tubercle or hump, on the dorsal line. Feet brown. Anal props striped with brown; abdominal props brown. Very short, sparse hairs all over the body. Head very smooth. Body arched when at rest, as before.

Aug. 20. 2nd moult. $\frac{3}{8}$ inch long. Head much larger than xst segment, clear green, glassy, with brown face-lines. Body glassy green, translucent, with very few hairs; a faint white lateral line, and a brown, broken substigmatal line appeared; the brown substigmatal patches on $5^{\text {th }}$ and roth segments were as before. $5^{\text {th }}$ segment had a large double hump, tipped with brown, I Ith had the large single hump as before; $4^{\text {th }}$ and 6th had each a double wart on dorsum. Feet brown and shining. Props pale brown banded with dark brown. Anal props slender. Rested arched as before. Ate the leaf from the edge to the mid-rib at the tip, and rested on the bared mid-rib. Aug. 2I. The marks had grown clearer and each segment from 6th to toth showed a small brown-tipped wart on the dorsal line, and from each wart a white oblique line extended downward and backward, on each side. On the first 3 segments a white subdorsal line appeared. The effect of the dorsal line was that of the edge of a serrate leaf.

Aug. 23. 3d moult. $\frac{8}{8}$ in. long. Head large, round, bilobed, smooth, green with dark face lines. Body green, with a broken, brown substigmatal line edged above with yellow, and a double yellow stigmatal line. First three segments had a double white subdorsal line. 4th segment had a double dorsal hump, tipped with brown; 5 th, a much larger double hump, yellow green, tipped with brown, the brown extending down the front and back like a dorsal line lifted by the hump! 6th to Ioth segments had similar humps, but smaller, like that on 4th. $x$ Ith segment had a large single hump with brown tip. From all these humps extended oblique white patches. Feet green with a dark, vertical line. Props pale brown 

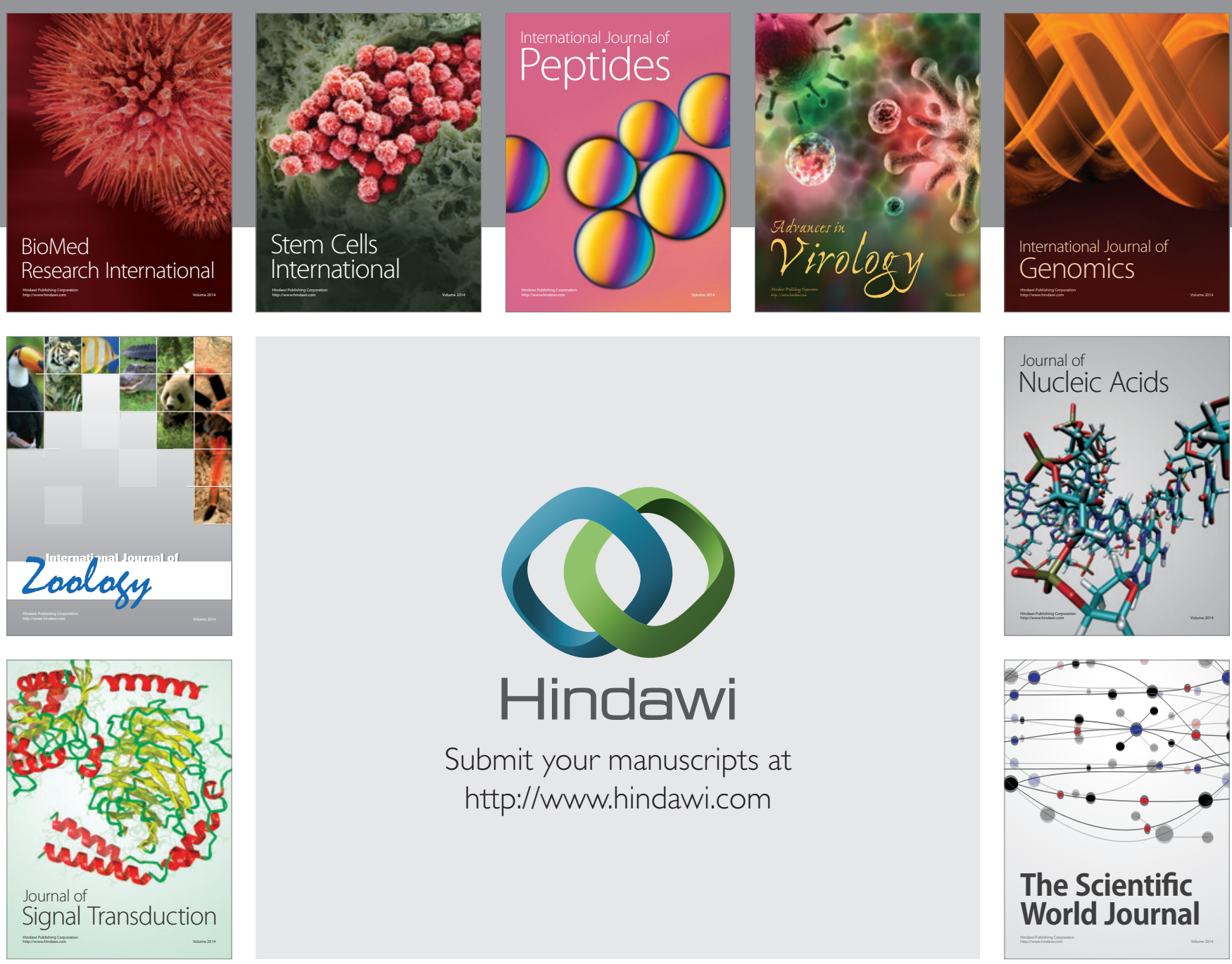

Submit your manuscripts at

http://www.hindawi.com
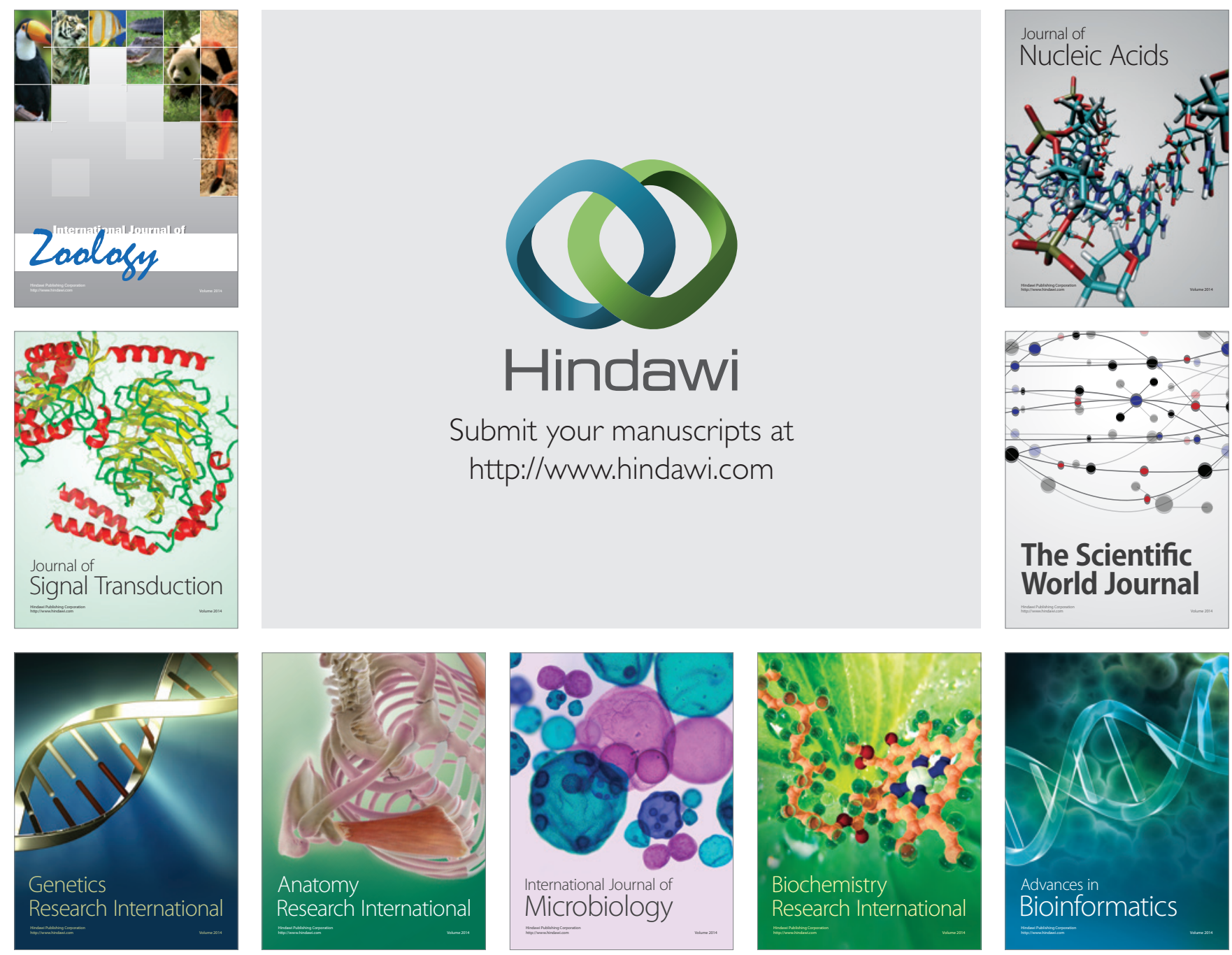

The Scientific World Journal
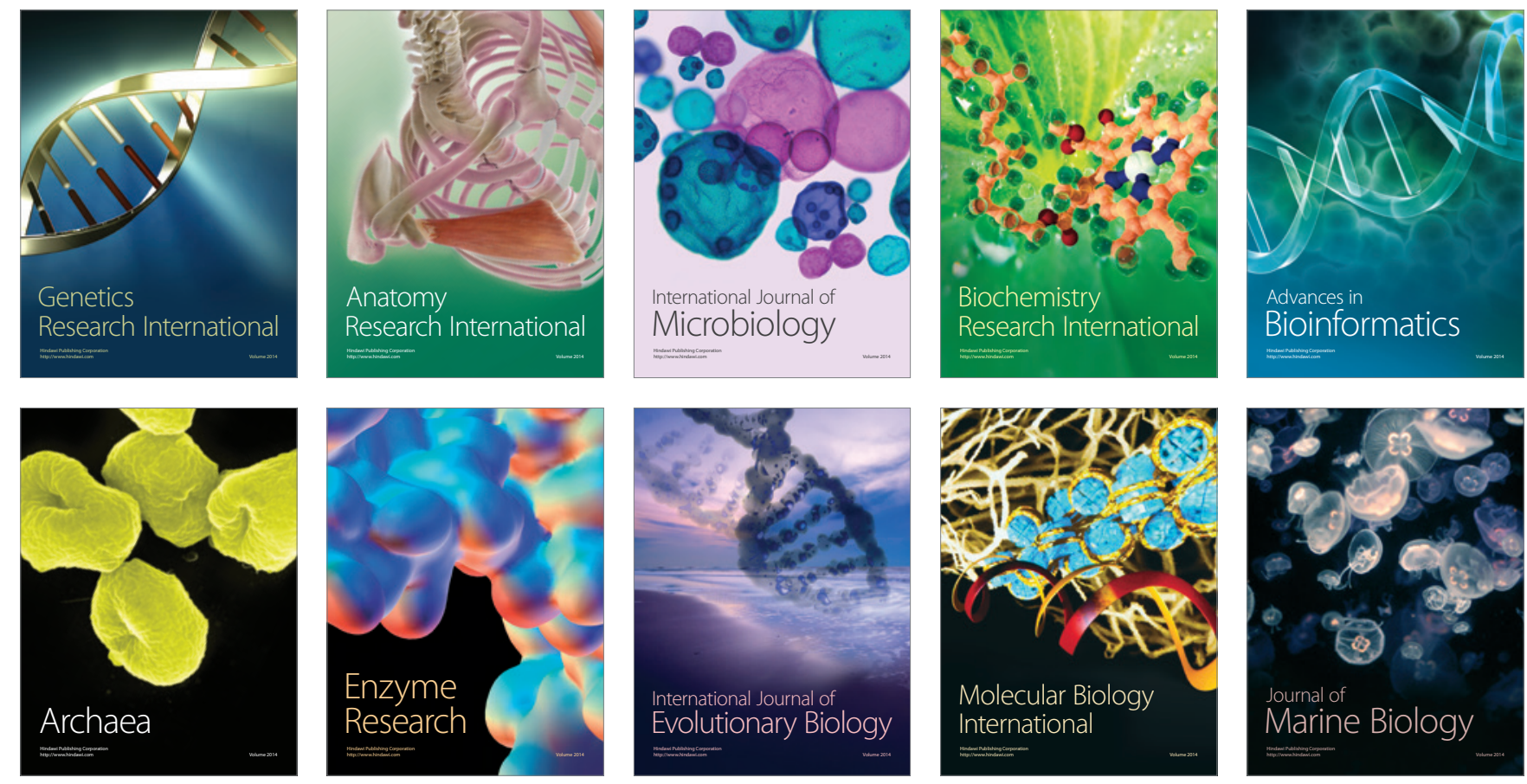